\title{
RESPONSES OF YOUNG TREES (FIVE SPECIES IN A CHAMBER EXPOSURE) TO NEAR-AMBIENT OZONE CONCENTRATIONS
}

\author{
M. S. GÜNTHARDT-GOERG, S. MAURER, J. BOLLIGER, A. J. CLARK, W. LANDOLT and J. B. \\ BUCHER \\ Swiss Federal Institute of Forest, Snow and Landscape Research, Zürcherstrasse 111, CH-8903 Birmensdorf \\ ZH, Switzerland
}

(Received 30 October 1998; accepted 26 February 1999)

\begin{abstract}
This investigation is intended to add to the quantitative information about the sensitivity of European deciduous tree species to environmentally realistic ozone $\left(\mathrm{O}_{3}\right)$ exposure in respect to the established critical level of an AOT40 of $10 \mathrm{ppm} . \mathrm{h}$ (6-month growing season, daylight hours). Cuttings (without leaves) of Fagus sylvatica L., Sorbus aucuparia, L., Carpinus betulus L.., Fraxinus excelsior L., and cuttings and seedlings of Prunus serotina Ehrh. were exposed during one growing season either to filtered air, to which $50 \%$ of ambient $\mathrm{O}_{3}$ concentration was added, or to $50 \%+30 \mathrm{ppb} \mathrm{O}_{3}$, resulting in a final AOT40 of 0.3 and $20.7 \mathrm{ppm} . \mathrm{h}$, respectively. The foliage formed per tree varied between and within the species, but was not significantly modified by $\mathrm{O}_{3}$, whereas the number of symptomatic leaves per tree significantly increased in the $50 \%+30 \mathrm{ppb}$ $\mathrm{O}_{3}$ regime. By mid July light-green spots appeared in the leaves (except $C$. betulus), which developed into stippling $\left(F\right.$. excelsior), red ( $P$. serotina) or necrotic spots by September. The $\mathrm{CO}_{2}$-assimilation rate decreased more with increasing visual symptoms (earliest in 20- day-old leaves) than with age-dependent leaf discoloration in $F$. sylvatica, $F$. excelsior, and $P$. serotina (not in $C$. betulus). The dark-adapted photosystem II quantum yield (Fv/Fm) slightly declined with leaf age, but a considerable reduction became apparent in 107-day-old leaves with $\mathrm{O}_{3}$-symptoms only. By late morning yield reductions in light-adapted leaves were exaggerated in such leaves from the $50 \%+30 \mathrm{ppb} \mathrm{O}_{3}$ regime. The above mentioned responses were not reflected in significant changes of the net biomass production during the experiment. The critical level, therefore, is based on visual and functional symptoms rather than on production.
\end{abstract}

Keywords: AOT40, assimilation rate, autumn leaf discoloration, biomass, chlorophyll fluorescence, critical level, visible symptoms

\section{Introduction}

Many different effects of $\mathrm{O}_{3}$ on trees (Sandermann et al, 1997) and the trees' defence mechanisms (Polle et al., 1999) have been reported based on at least double-ambient $\mathrm{O}_{3}$ concentrations, but the derivation of a critical level for near-ambient $\mathrm{O}_{3}$ concentrations is still a controversial issue. A provisional critical level for $\mathrm{O}_{3}$ has been established (Fuhrer and Achermann, 1994; Lucas and Skärby, 1994) as $10 \mathrm{ppm} . \mathrm{h}$, calculated as a cumulative exposure above the threshold of $40 \mathrm{ppb}$ (AOT40). The AOT40 was calculated on a $24 \mathrm{~h}$ basis because there is some evidence that stomata may not close entirely during night-time (Matyssek et al., 1995) and that mechanisms responsible for detoxification of $\mathrm{O}_{3}$ or its reaction products may be reduced in darkness. It was further accepted that a seasonal time of 6 months should cover the most sensitive period of the trees and that plants ought to be protected from a $10 \%$ loss in net biomass production by this critical value, even though the latter has been determined on the data from only a small number of experiments. The

Water, Air, and Soil Pollution 116: 323-332, 1999.

(1) 1999 Kluwer Academic Publishers. Printed in the Netherlands. 
provisional critical level of $10 \mathrm{ppm} . \mathrm{h}$ has been exceeded in 'non-smog' areas like southern Sweden (data from 1990 - 93, Kindbom et al., 1995) and also in the mountainous regions of Switzerland, where $\mathrm{O}_{3}$-concentrations almost doubled between the fifties and the nineties (Staehelin et al., 1994). The calculation of the critical level has been modified since by confining the exceedance to the daylight hours only (calculated global clear-sky radiation above $50 \mathrm{Wm}^{-2}$ ) similar to that for agricultural plants (Skärby and Skeffington, 1996). New experimental data were provided in 1996 to support the AOT40 of $10 \mathrm{ppm}$.h from a significant regression of biomass production of 0-3 year-old Fagus sylvatica versus AOT40 (daylight hours), established by normalising data from three different projects (Braun and Flückiger, 1995, Steingröver et al., 1995, Küppers et al., 1994). Because this data base is still insufficient, the present investigation has been designed to add to the quantitative information about the sensitivity of different deciduous tree species to realistic $\mathrm{O}_{3}$ concentrations in respect to the critical level established in 1996 . The $\mathrm{O}_{3}$ scenarios therefore were established in the present study to represent a background concentration (50\% ambient) vs. a near-ambient AOT40 of twice the critical level of $10 \mathrm{ppm} . \mathrm{h}$ (characteristic for higher altitudes of 1600-1800 $\mathrm{m}$ a.s.l. in Switzerland).

\section{Materials and Methods}

The experiment took place in two large $\left(10 \mathrm{~m}^{2}\right.$ each, wind speed $\left.0.5 \mathrm{~ms}^{-1}\right)$ walk-in climate chambers, where the climatic parameters (temperature, humidity and light hours) reflected the means of ambient climate measurements at the experimental site (Zürich, Switzerland) from May to November over a period of ten years (modified from Günthardt-Goerg $e t$ al., 1996). The chambers were supplied with charcoal and Purafil filtered air, to which $50 \%$ of the current year ambient $\mathrm{O}_{3}$ concentration (area within the buildings of the institute) was added $\left(\mathrm{O}_{3}\right.$ generated from pure oxygen), or $50 \%+30 \mathrm{ppb}$, resulting in a final AOT40 of $0.3(\mathbf{A}-)$, and $20.7 \mathrm{ppm} . \mathrm{h}(\mathbf{A}+)$ respectively (Fig. 1). $\mathrm{O}_{3}$ concentrations within the chambers were adjusted by mass flow controllers and monitored as in ambient air in the area of the buildings and at the forest edge using Monitor Labs Model 8810 instruments, which were calibrated against each other. Sorbus aucuparia, L. grafted stock, Carpinus betulus L., Fraxinus excelsior L., Fagus sylvatica L., and Prunus serotina Ehrh. rooted cuttings (without leaves, 16 per species, 8 each from 2 clones, 4 per clone and chamber) and $16 \mathrm{P}$. serotina seedlings taken from a native forest in the south of Switzerland, were weighed, potted (10 1/plant) and exposed from May 5th to November 15th. Nutrients were applied by a slow-release fertiliser with a life span of 6 months (Osmocote, Sierra Chemical Europe, The Netherlands, initial N:P:K = 315:98:221). Phenology of each leaf per tree cutting or seedling was estimated monthly for visible symptoms (spots or stippling) and leaf colour.

One leaf of each tree was labelled during flushing and measured at the age of 20 (4 August), 67 (20 September) and 107 (31 October) days. During daylight hours (9 a.m. to $5 \mathrm{p} . \mathrm{m}$.) leaf gas exchange was measured at the light conditions of the chambers and at light-saturated conditions with a portable $\mathrm{CO}_{2} / \mathrm{H}_{2} \mathrm{O}$ porometer (Model CQP-130, Walz, Effeltrich, Germany) at ambient (chamber) temperature, air humidity, and $\mathrm{CO}_{z}$ concentration (leaf area enclosed into the cuvette: $7.5 \mathrm{~cm}^{2}$ ). The dark adapted 
photosystem II quantum yield (Fv/Fm, calculated as 1 - Fo/Fm; measured from 3 a.m. to before dawn) and the light adapted photosystem II quantum yield ( $\delta \mathrm{F} / \mathrm{Fm}$, calculated as 1 - Fo'/Fm'; measured from 10 a.m. to 12 a.m.) were determined for the same leaves using the 'pulse-amplitude modulation' method for chlorophyll fluorescence (Model PAM-2000, Walz, Effeltrich, Germany). For each leaf, four measurements were made by applying saturation pulses of $1000 \mu \mathrm{mol}$ photons $\mathrm{m}^{-2} \mathrm{~s}^{-1}$ and $0.8 \mathrm{~s}$ in duration. The
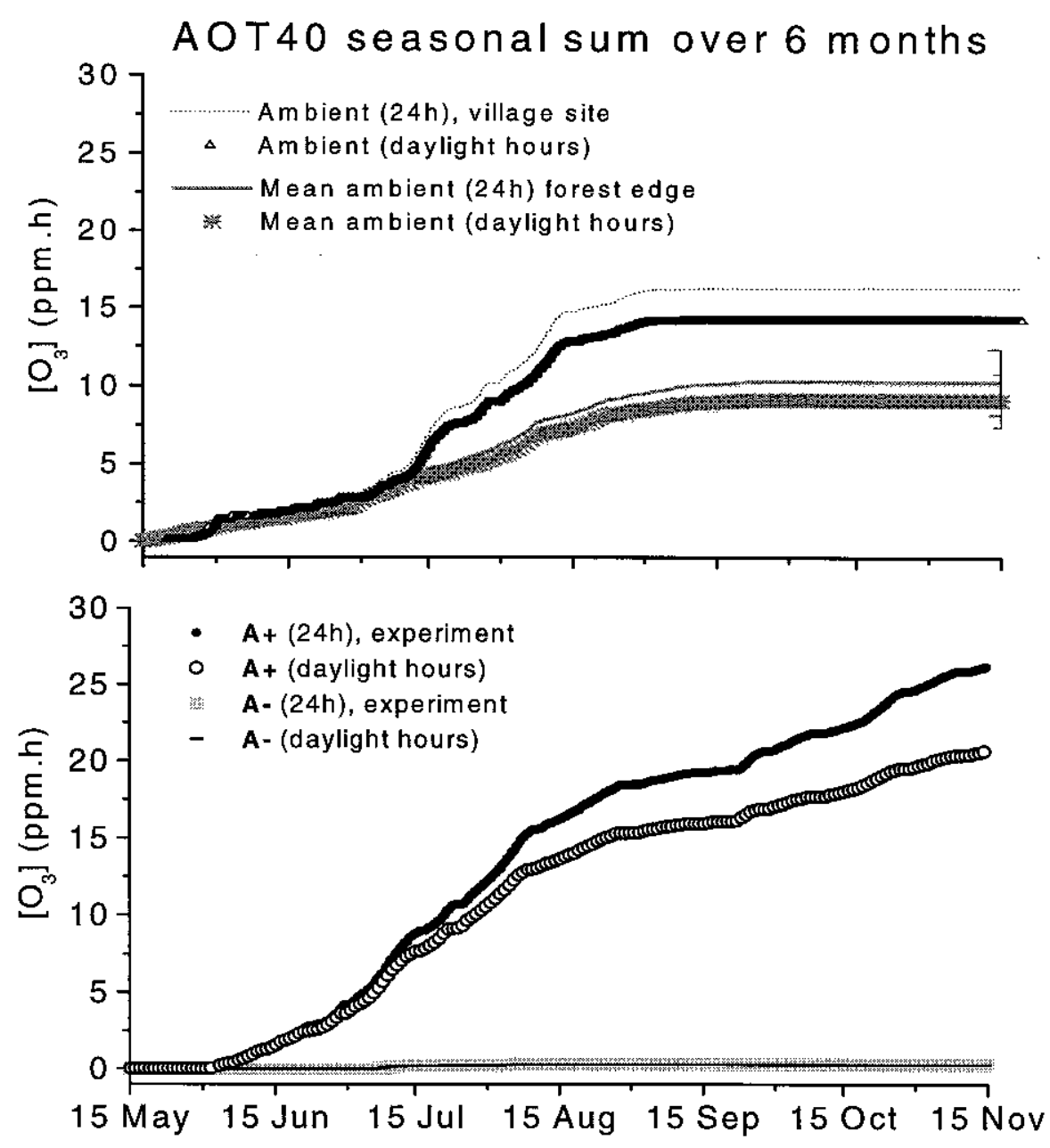

Fig. 1: AOT40 was calculated as the sum of hourly $\mathrm{O}_{3}$ concentrations above $40 \mathrm{ppb}$ during $24 \mathrm{~h}$ or daylight hours (ambient $>50 \mathrm{~W} \mathrm{~m}^{-2}$, experiment $\geq$ PPFD $400 \mu \mathrm{mol} \mathrm{m}^{-2} \mathrm{~s}^{-1}$ ) over the 6-month growing season of the experiment.

Ambient air: AOT40 for ambient air within the area of the buildings of our institute 1995; mean ambient $( \pm \mathrm{SE}) \mathrm{O}_{3}$ concentrations from the forest edge, Birmensdorf, Switzerland (1991 - 1995).

Experiment: $\mathbf{A} \cdot=$ AOT 40 as $50 \%$ ambient $1995, \mathbf{A}+=$ AOT 40 as $50 \%$ ambient $+30 \mathrm{ppb}$. 
photon flux density of the measuring light provided by the PAM-2000 unit was $<1$ $\mu \mathrm{mol} \mathrm{m} \mathrm{m}^{-1}$. In the final harvest, foliage area and net production of foliage, wood and root dry mass were determined for each plant.

Pooled data were analysed for each measured parameter with multiple factor ANOVA, but comparative tests were made between date, species (both clones, because no difference was found between the clones), light conditions for gas exchange and $\mathrm{O}_{3}$ regimes with one-way ANOVA (GLM procedure, SAS Institute Inc. 1985). Where significant treatment effects were detected, means were separated using the HSD test. AOT40 was calculated over the 6-month growing season of the experiment by the sum of hourly $\mathrm{O}_{3}$ concentrations exceeding $40 \mathrm{ppb}$ during either $24 \mathrm{~h}$ or daylight hours. The sum of daylight hours was calculated (according to Bruck et al., 1985) using light intensities $>50 \mathrm{~W} \mathrm{~m}^{-2}$, which for the chambers was equivalent to a PPFD equal to or greater than $400 \mu \mathrm{mol} \mathrm{m} \mathrm{m}^{-2}$.

\section{Results and Discussion}

Usually at a forest edge in the neighbourhood of our institute the seasonal mean AOT40 for $\mathrm{O}_{3}$ is below the $10 \mathrm{ppm} . \mathrm{h}$ limit (Fig. 1, mean ambient $=9.1 \mathrm{ppm} . \mathrm{h}$ ) and visible leaf symptoms in trees are rarely found, whereas less than $500 \mathrm{~m}$ from the forest edge ambient AOT40 within the area of the buildings amounts to $14.1 \mathrm{ppm} . \mathrm{h}$ reflecting a rural village site in the Swiss midland (Fig. 1, ambient). The latter measurements were used for our experiment, namely the $50 \%$ ambient $\mathrm{O}_{3}$-regime (Fig. $1 \mathrm{~A}$-), which did not exceed the limit of $40 \mathrm{ppb}$, and the $50 \%$ ambient $+30 \mathrm{ppb}_{3}$-regime, which often did. Ail exceedance summed up over the season reached an AOT40 of 20.7 ppm.h (Fig. 1, A+ on a daylight hour basis).

The deciduous trees used in the experiment had different growth habits that were dependent on the species and propagation. $P$. serotina vegetatively propagated from cuttings produced 5 times more foliage area than $P$. serotina propagated from seeds, and 16 times more than $F$. sylvatica cuttings. The foliage of $C$. betulus cuttings entirely originated from primary buds which were present when the cuttings were exposed; other species formed new secondary buds during the season. This 'secondary foliage' tended to be increased by $\mathbf{A}+$ (vs. A-), but great variations in foliage area did not allow a significant change to be detected (Fig. 2). In P. serotina, from seed, autumnal leaf discoloration (yellowing, reddening or bronzing) had already started in July, significantly earlier than in the other trees including $P$. serotina grown from cuttings (Fig. 3, white bar parts). Leaf discoloration and shedding, although differing by species and propagation did not significantly change by the addition of $30 \mathrm{ppb}_{3}$ (Fig. 3, white and black bar parts, A+ vs. A-). Independent of leaf discoloration, a wide variety of leaf symptoms (spots) was formed particularly in the At. By mid July light-green spots appeared in the leaves of $F$. sylvatica cuttings, $P$. serotina seedlings and cuttings, and $S$. aucuparia cuttings, whereas $C$. betulus and $F$. excelsior still showed green leaves. These symptoms developed, into necrotic spots in $F$. sylvatica, and $S$. aucuparia, and into red spots in P. serotina by September. In September F. excelsior initially exhibited light green 


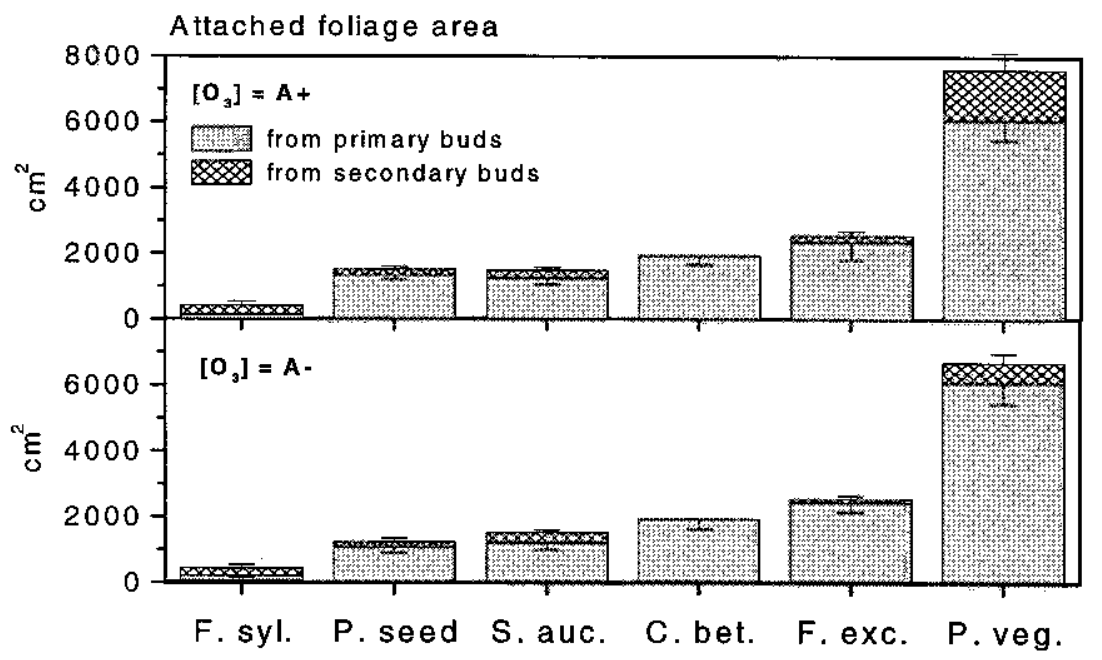

Fig. 2: Attached foliage area at the harvest date November 15 th in the $\mathbf{A}$ - and $\mathbf{A}+\mathrm{O}_{3}$-regime of the experiment. Primary buds = buds formed when the cuttings were exposed in May, secondary buds = buds formed during the exposure time. Means are plotted from 8 trees each, standard error is shown positively for the cross-hatched bars representing foliage from secondary buds, but negatively from primary buds (shaded bar). Abbreviations: $F$. syl. $=$ Fagus sylvatica, $P$. seed $=P$. serotina propagated from seeds, $S$. auc. $=$ Sorbus aucuparia, $C$. bet. $=$ Carpinus betulus, $F$. exc. $=$ Fraxinus excelsionr, and $P$. veg. $=$ Prunus serotina propagated from cuttings.

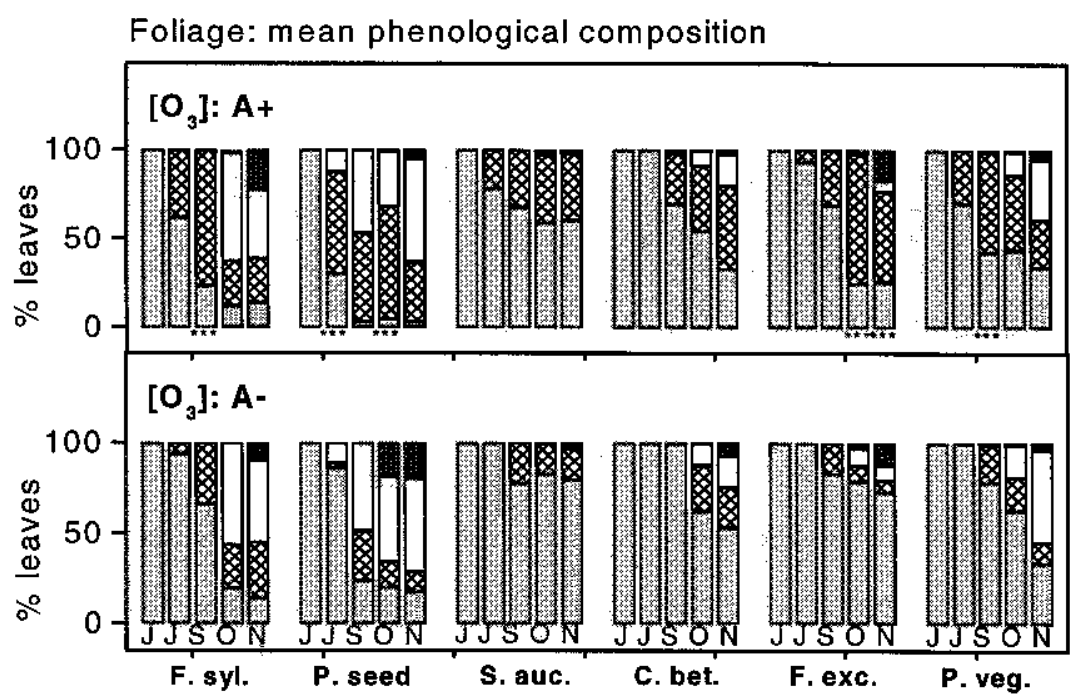

Fig. 3: Foliage phenology (monthly estimated) in all individual leaves per tree (tree order with increasing foliage production and species abbreviation according to Fig. 2). The stacked bars represent the mean percent foliage composition (means from 8 trees each) per species or propagation in each $\mathrm{O}_{3}$ regime from June to November. Green leaves are plotted light grey, leaves with $\mathrm{O}_{3}$-symptoms (or in the A- with ' $\mathrm{O}_{3}$-like' symptoms) crosshatched, leaves with autumnal discoloration white, and shed leaves black. ${ }^{* *}$ in $\mathbf{A}+$ indicate a significant difference $(\mathrm{p}<0.05)$ of the green and symptomatic foliage to the corresponding means in A-. 
leaf tips and margins, which later developed into stippling, in C. betulus leaf bronzing only began at the margins in September. Leaf sensitivity to $\mathrm{O}_{3}$ in terms of early appearance of leaf symptoms was at the highest in $F$. sylvatica and $P$. serotina from seeds (Fig. 3, cross hatched bar parts, beginning in July) which both had formed the smallest foliage area, in contrast to $C$. betulus and $F$. excelsior, although their foliage was older (originated from primary buds, Fig. 3 vs. Fig. 2). However, in vegetatively propagated P. serotina, the indeterminate growth habit had contributed to more green foliage relative to the symptomatic foliage at the end of the season than in P. serotina grown from seeds (Fig. 3, A+). Similar differences between seedlings, saplings and canopy trees have been observed in Pennsylvania (USA) by Fredericksen et al. (1996).

Nevertheless the number of green leaves (Fig. 3, light grey bar parts) per tree decreased in favour of more leaves with $\mathrm{O}_{3}$-symptoms (cross-hatched) in the $\mathbf{A}+$ (significant effects, $\mathrm{p}=0.001$ for each of the factors $\mathrm{O}_{3}$ - regime, month and species). The difference of the means had to be large to overcome the great variability among the individuals. Depending on the species, the largest difference in symptomatic and green foliage occurred in July, September or October. Particularly in P. serotina and $F$. sylvatica, $\mathrm{O}_{3}$-symptoms were combined with autumnal leaf discoloration at the end of the season.

Leaf gas exchange and chlorophyll $a$ fluorescence emission values differed between the species, leaf age, and $\mathrm{O}_{3}$-regimes, with $F$. excelsior showing the highest assimilation rate. Overall (pooled data) leaf age and species were significant factors at $p=0.0001$; $\mathrm{O}_{3}$-regime was significant at $\mathrm{p}=0.0001$ for transpiration rate and $\mathrm{p}=0.011$ for assimilation rate, and not significant for $\mathrm{Fv} / \mathrm{Fm}$ or $\delta \mathrm{F} / \mathrm{Fm}^{\prime}$. In $S$. aucuparia and $C$. betulus, which showed no significant difference in the number of symptomatic leaves per tree (Fig. 2), the leaf gas exchange and chlorophyll fluorescence properties also did not change with increasing leaf age or $\mathrm{O}_{3}$-regime. In contrast, functional changes due to $\mathbf{A +}$ (vs. A-) and increasing leaf age were similar in leaves of $F$. sylvatica, $F$. excelsior and $P$. serotina, though the development of their visible symptoms differed.

The assimilation rate of green 20-day-old leaves of $F$. sylvatica, $F$. excelsior and $P$. serotina (A- and A+, e.g. F. sylvatica, Fig. 4) was higher than that of leaves with visible light-green spots (in A+ only). The assimilation rate tended to decline further with leaf age, when the symptoms developed into necrotic spots in A+ relative to A-. A small decline was also apparent in the oldest leaves with age-dependent discoloration. The transpiration rate tended to be lower in the older leaves with established visible symptoms in A+ vs. A-. There was no significant difference between the gas exchange measured at the light conditions of the chambers and that measured at light-saturation.

$\mathrm{Fv} / \mathrm{Fm}$, the maximum potential quantum yield, represents photosystem II efficiency for primary photochemistry. The values measured predawn indicate a relatively recovered state of the photosystem II during night-time. Fv/Fm remained nearly unchanged with increasing leaf age in the A- in all species (for example $F$. sylvatica, Fig. 5), but clearly declined in 107-day-old leaves with $\mathrm{O}_{3}$-symptoms (A+) of $F$. sylvatica and $F$. excelsior (not $P$. serotina). In the measurements of light adapted leaves (with biochemical limitations on the electron transport), $\delta \mathrm{F} / \mathrm{Fm}$ ' tended to decrease in all species with leaf age and discoloration in the A-, but this trend was exaggerated in the 107-day-old leaves with $\mathrm{O}_{3}$-symptoms (e.g. F. sylvatica, Fig. 5, A+). 


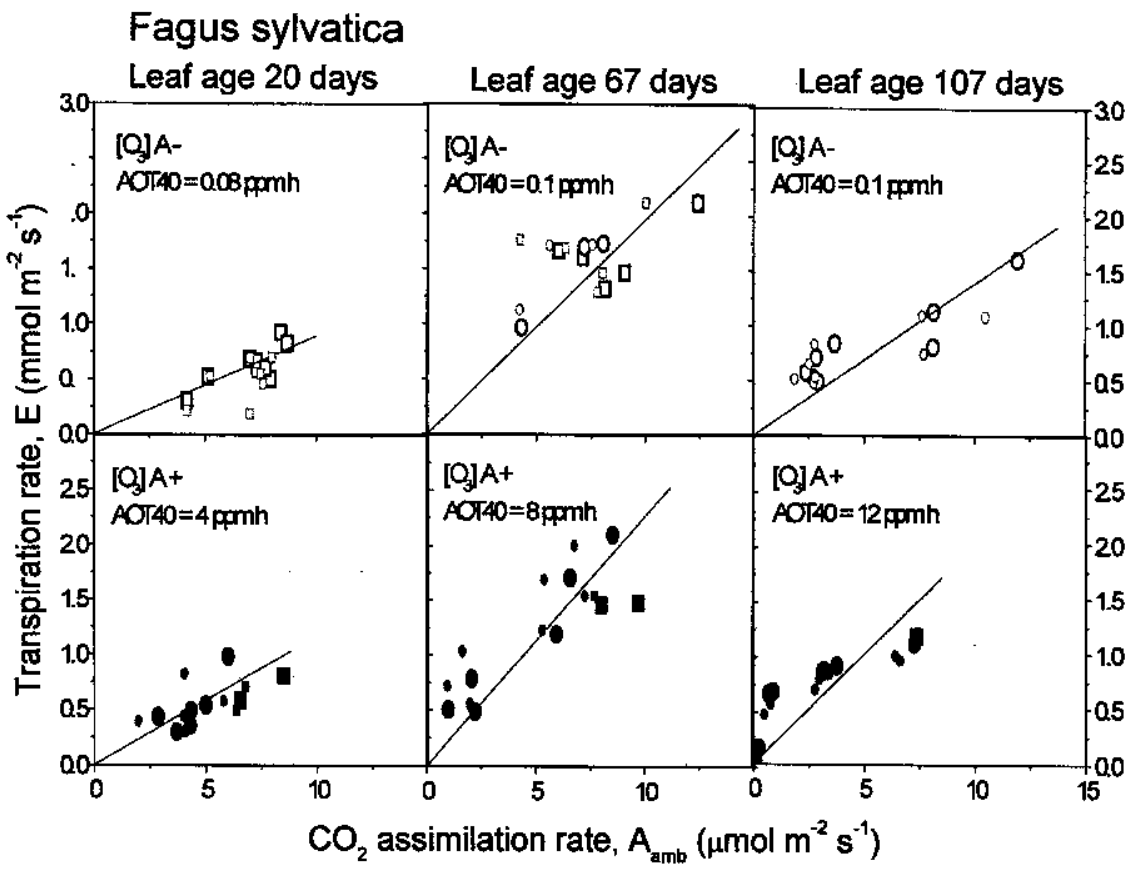

Fig. 4: F. sylvatica (for example): Leaf gas exchange (details see methods) from leaves which had been labelled after flushing and measured when 20-,67- and 107-day-old at light-saturation and at the chamber light conditions (smaller symbols). AOT40 was calculated for those leaf ages (daylight hour basis). A - open squares $=$ green leaves, open circles $=$ leaves with autumnal discoloration $. \mathbf{A}+$ solid squares $=$ green leaves, solid circles $=$ leaves with $\mathrm{O}_{3}$-symptoms (light-green spots when 20-day-old, later developing to necrotic spots).

The fact that the decline in the $\mathrm{CO}_{2}$ assimilation rate had already appeared in 20-day-old leaves in the A+, whereas the fluorescence measurements of photosystem II only became apparent in 107-day-old leaves, demonstrated that the quantum yield of photosystem II can be more stable than $\mathrm{CO}_{2}$ assimilation (similar to findings for birch, Maurer et al., 1997). However, both assimilation rate and quantum yield of photosystem II measured in leaves with conspicuous $\mathrm{O}_{3}$-symptoms still showed photosynthetic activity, but at a reduced level compared with green leaves. Visible symptoms and functional decline occur due to changes at the cellular level (Günthardt-Goerg et al., 1997). Isolated or groups of injured cells are unevenly distributed within a leaf, as are other cells which appear to be highly efficient and balance the injured cells.

The $\%$ change of the mean values of different parameters for $\mathbf{A}+$, relative to $\mathbf{A}$ - are conspicuous (Fig. 6). They show:

1) less green leaves (grey bars), but more leaves with $\mathrm{O}_{3}$-symptoms (cross-hatched).

2) larger leaf area formed from secondary buds (horizontally hatched) in $F$. sylvatica, $F$. excelsior and vegetatively propagated $P$. serotina.

3) reduced assimilation rate (left hatched) and transpiration rate (right hatched), except in C. betulus.

4) a small, not significant reduction of the net whole tree biomass (black bars), except in vegetatively propagated $P$. serotina with their prominent second flush. 


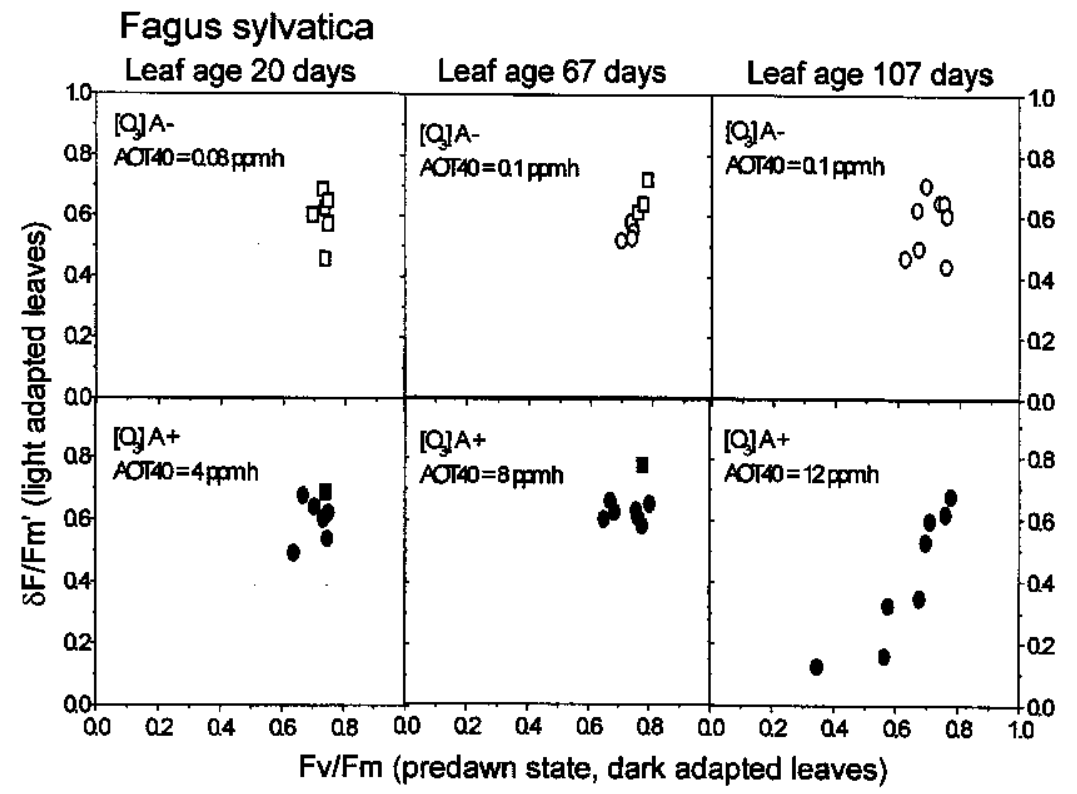

Fig. 5: F. sylvatica (for example): Maximum potential quantum yield, representing photosystem II efficiency (Fv/Fm in dark-adapted leaves, $\delta$ F/Fm' in light adapted leaves), the same leaves as Fig. 4.

Neither foliage, stem, root biomass, nor their ratios were significantly changed by A+ with AOT40 $=20.7 \mathrm{ppm}$.h (data not included). A 10\% biomass reduction for AOT $40=10 \mathrm{ppm}$.h cannot be confirmed by this experiment or by a similar study (Landolt et al., 1996). Because earlier experiments have not been designed and calculated for the evaluation of critical levels, the present critical level of $10 \mathrm{ppm} . \mathrm{h}$ is still based on a few open-top chamber experiments with $F$. sylvatica: (1) an experiment with $F$. sylvatica in unfiltered vs. filtered ambient air with prevailing $\mathrm{O}_{3}$ pollution (seedlings from the cotyledon stage over a 1-3 season period, Braun and Flückiger, 1995), (2) an experiment with simulated ambient pollution mixtures (2-year-old $F$. sylvatica seedlings over a 2 season period, Küppers et al., 1994), (3) an experiment with different $\mathrm{O}_{3}$-concentrations (final AOT40 $=0,20,40$ and 80 ppm.h, 3-year-old old $F$. sylvatica saplings, Steingröver et al., 1995). Other experiments with juvenile deciduous trees report significant biomass reductions for $\mathrm{O}_{3}$-sensitive species or genotypes (Populus tremuloides Michx. cuttings and seedlings, AOT40 $=50-92 \mathrm{ppm} . \mathrm{h}$, seasonal exposure, Karnosky et al., 1996; $P$. serotina seedlings, AOT40 $=28.3$ or 40.4 ppm.h, seasonal exposure, Neufeld et al., 1995; Betula pendula Roth. clones, AOT40 $=18$ ppm.h over a 2 season period, Pääkkönen et al., 1997). To support or reject the present critical level of AOT $40=10 \mathrm{ppm} . \mathrm{h}$ in respect to significant biomass reduction in young deciduous trees, more experimental data with AOT40 near $10 \mathrm{ppm} . \mathrm{h}$ are needed.

At least in Europe it is difficult to find any growth reductions in mature trees due to $\mathrm{O}_{3}$. Forest inventories show increasing growth trends of mature trees, which appear to be based on land use history and forest management (Spiecker, 1999). However, visible $\mathrm{O}_{3}$-symptoms may correlate to reduced growth; recently significant intraspecific radial growth reductions over a 5- and 10-year period have been reported in mature 
Liriodendron tulipifera $\mathrm{L}$. with visible foliar injury, as compared to non symptomatic trees, and in contrast to no significance within $P$. serotina in the Great Smoky Mountains, USA (Somers et al., 1998).

A+: percent change to A-

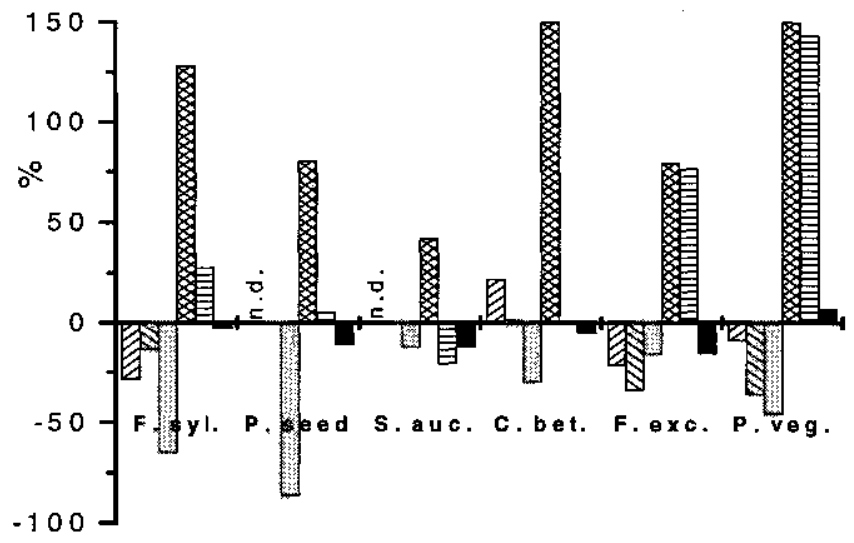

Fig. 6: Means of different parameters from the A+ plotted as percent change relative to those from the A- (Fig. 2 for species abbreviation). Left hatched bars $=$ assimilation rate, right hatched bars $=$ transpiration rate (both pooled over all leaf ages, not determined $=\mathbf{n}$.d. in $P$. serotina from seeds and $S$. aucuparia). Grey bars $=$ green foliage (number of leaves), crosshatched bars = foliage with leaf symptoms in September (more than $150 \%$ increase for $C$. betulus and $P$. serotina cuttings. Horizontally hatched bars = leaf area originating from secondary buds, black bars $=$ net whole tree biomass production by November 15 th .

\section{Conclusions}

The seasonal AOT40 of ambient air can vary within a $500 \mathrm{~m}$ distance by $5 \mathrm{ppm} . \mathrm{h}$. Visible symptoms and reductions in leaf gas exchange of $F$. sylvatica, $F$. excelsior and $P$. serotina have been detected in the present study between an AOT40 of 4 and 12 ppm.h, and reductions in the quantum yield of photosystem II (two European species only) at AOT40 of $12 \mathrm{ppm} . \mathrm{h}$. Certain deciduous tree species, therefore, appear to be more sensitive than shown in earlier experiments $(40 \mathrm{ppm} . \mathrm{h}<F$. sylvatica $<80 \mathrm{ppm} . \mathrm{h}$, Lippert et al., 1996). However, in the Swiss midland with about 30-50 'summer smog days' (Brönnimann and Neu, 1997) the AOT40 of $10 \mathrm{ppm} . \mathrm{h}$ is not regularly achieved, and $\mathrm{O}_{3}$-symptoms are rare (except in certain regions in the south, Skelly et al., 1999) or occur late in the summer, when they are mixed up with autumnal discoloration.

In the present study leaf discoloration was not related to the $\mathrm{O}_{3}$ regime. Discoloration therefore should be separated from the estimation of visible speciesspecific $\mathrm{O}_{3}$ symptoms (spots and stippling).

A realistic critical level should take into account that the leaf sensitivity to $\mathrm{O}_{3}$ varies not only within a tree species, within genotypes, and individual trees, but is also dependent on tree propagation. The single leaf sensitivity to $\mathrm{O}_{3}$ varies greatly between species, but can be independent of the foliage productivity or the growth habits of the trees.

Visible symptoms and concomitant functional reductions are not necessarily reflected in significant changes of net biomass production. Young and even older trees may have a 
surplus of leaves, and cope with a certain premature foliage loss without significant consequences for growth parameters. The present critical level for $\mathrm{O}_{3}$, therefore, can be based on visual and functional symptoms rather than net biomass production.

\section{Acknowledgements}

We gratefully acknowledge the technical assistance of D. Mathies, P. Bleuler and D. Tarjan.

\section{References}

Braun, S. and Flückiger, W.: 1995, New Phytol. 129, 33-44.

Brönnimann, S. and Neu, U.: 1997, Atmos. Environ. 31, 1127-1135.

Bruck, M., Hammer, N., Neuwirth, F. and Schaffar, S.: 1985, Meteorologische Daten und Berechnungsverfahren, 3. Auflage, dbv-Verlag, Wien.

Fredericksen, T.S., Skelly, J.M., Steiner, K.C., Kolb, T.E. and Koutrick, K.B.: 1996, Environ. Pollut. 91, 5363.

Fuhrer, J. and Achermann, B. (eds.): 1994, Critical levels for ozone: a UN-ECE workshop report. Schriftenreihe der FAC Liebefeld, 16, FAC Liebefeld, Switzerland.

Günthardt-Goerg, M. S., Schmutz, P., Matyssek, R. and Bucher, J. B.: 1996, Can. J. For. Res. 26, 649-657.

Günthardt-Goerg, M.S., McQuattie, C.J., Scheidegger, C., Rhiner, C. and Matyssek, R.: 1997, Can. J. For. Res. 27, 453-463.

Kärenlampi, L. and Skärby, L. (eds.): 1996, Critical levels for ozone in Europe-Testing and finalizing the concepts UN-ECE workshop report. University of Kuopio, Kuopio, Finland.

Karnosky, D.F., Gagnon, Z.E., Dickson, R.E., Coleman, M.D., Lee, E.-H. and Isebrands J.G.: 1996, Can. J. For. Res. 26, 23-37.

Kindbom, K., Lövblad, G., Peterson, K. and Grennfelt, P.: 1995, Ecol. Bull. 44, 35-42.

Küppers, K., Boomers, J., Hestermann, S., Hanstein, S. and Guderian, R.: 1994, in Critical levels for ozone a UN-ECE workshop report. Fuhrer, J. and Achermann, B. (eds.), pp. 98-110. Schriftenreihe der FAC Liebefeld, vol. 16, FAC Liebefeld, Switzerland.

Landolt, W., Bucher, J. B., Pfenninger, I. and Bleuler, P.: 1996, in Critical levels for ozone in Europe: Testing and finalizing the concepts. Kärenlampi, L. and Skärby, L. (eds.), pp. 244-248, University of Kuopio, Finland.

Lippert, M., Steiner, K., Payer, H. D., Simons, S., Langebartels, C. and Sandermann, H.Jr.: 1996, Trees 10, 268-275.

Lucas, P. and Skärby, L.: 1994, in Critical levels for ozone a UN-ECE workshop report, Fuhrer, J. and Achermann, B. (eds.), pp.14-16, Schriftenreihe der FAC Liebefeld, vol. 16, FAC Liebefeld, Switzerland. Matyssek, R., Günthardt-Goerg, M.S., Maurer, S. and Keller, T.: 1995, Tree Physiol. 15, 159-165.

Maurer, S., Matyssek, R., Günthardt-Goerg, M. S., Landolt, W. and Einig, W.: 1997, Trees 12, 1-10.

Neufeld, H.S., Lee, E.H., Renfro, J.R., Hacker, W.D. and Yu, B.H.: 1995, New. Phytol. 130, 447-459.

Pääkkönen, E., Holopainen, T. and Kärenlampi, L.: 1997, Environ. Pollut. 95, 37-44.

Polle, A., Matyssek, R., Günthardt-Goerg, M.S. and Maurer, S.: 1999, in Environmental pollution and plant responses, Agrawal,S.,Agrawal,M. and Krizek,D.T.(eds.),CRCPress/Lewis Publishers, New York, in press Sandermann, H. Jr., Wellburn, A.R. and Heath, R.L.: 1997, Ecological Studies 127, Springer, Berlin.

Skärby, L. and Skeffington, R.: 1996, in Critical levels for ozone in Europe:Testing and finalizing the concepts UN-ECE workshop report. Kärenlampi, L. and Skärby, L. (eds.), pp.18-23, University of Kuopio, Kuopio, Finland.

Skelly, J., Innes, J. L., Savage, J. E., Snyder, K. R., Vanderheyden, D., Zhang, J. and Sanz, M. J.: 1999, Water Air Soil Pollut. (this volume)

Spiecker, H. : 1999, Water Air Soil Pollut. (this volume)

Somers, G. L., Chappelka, A. H., Rosseau, P. and Renfro, J. R.: 1998, For. Ecol. Manage. 104, 129-137.

Staehelin, J., Thudium, J., Buehler, R., Volz-Thomas, A. and Graber, W.: 1994, Atmos. Environ. 28, $75-87$.

Steingröver, E., Dueck, T. and van der Eerden, L.: 1995, in Acid Rain Research: Do we have enough answers " G.J. Heij and W.J. Erisman (eds.), pp. 213-222, Elsevier Science BV, Amsterdam. 